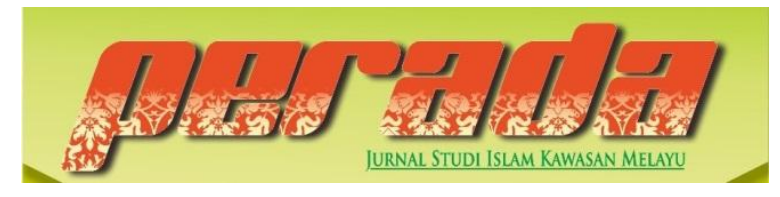

\author{
Perada: Jurnal Studi Islam Kawasan Melayu \\ P-ISSN 2656-7202 E-ISSN 2655-6626 \\ Volume 2 Nomor 1, Januari-Juni 2019 \\ DOI: 10.35961/perada.v2i1.27
}

\title{
KESAN HADIS MAUDHU’ DALAM AMALAN UMAT ISLAM
}

\author{
Siti Marpuah \\ Pensyarah Jabatan Pengajian Islam, Pusat Pengajian Umum dan Kokurikulum \\ Universiti Tun Hussein Onn Malaysia \\ marpuab@uthm.edu.my \\ Farah Darwisyah Binti Ahmad Zamree \\ Pelajar Pengajian Islam, Universiti Tun Hussein Onn Malaysia
}

\begin{abstract}
ABSTRAK
Hadis Maudhu' adalah sesuatu yang disandarkan kepada Nabi Muhammad s.a.w samaada perbuatannya, perkataannya, taqrirnya, sifat akhlaqnya atau sifat semulajadinya, secara rekaan atau dusta semata-mata. Di dalam penggunaan masyarakat Islam di negara kita, hadis maudhu' disebut juga dengan nama hadis palsu. Kajian ini bertujuan untuk melihat apakah faktor kemunculan hadis maudhu' serta kesannya terhadap amalan beribadah umat Islam sekarang ini. Kajian ini merupakan kajian kualitatif melalui temu bual serta pengumpulan dokumen berupa kitab-kitab hadis. Hasil kajian menunjukkan bahawa faktor kemunculan hadis maudu' adalah adanya musuh Islam yang ingin merosakkan hadis yang betul, sikap fanatik terhadap kumpulan, sikap ambil mudah dalam meriwayatkan hadith, sikap kepentingan diri dan mencari kemasyhuran orang ramai, Kejahilan tentang ajaran Islam yang sebenar. Kesan hadis maudhu' merosakkan akidah umat Islam, Merosakkan amalan syariah umat Islam, Merosakkan akhlak umat Islam, Merosakkan pendirian umat Islam, Mengabaikan hadith sahih. Untuk itu pengkaji mencadangkan supaya umat Islam lebih berhati-hati dalam memahami sesuatu hadis serta mengamalkannya, kerana ditakutkan ianya merupakan hadis maudu' atau hadis palsu.
\end{abstract}

ABSTRACT: Hadith Maudhu' 'is something that is attributed to Prophet Muhammad s.a.w whether it is his actions, his words, his taqrir, his morality or his natural state, falsely or simply. In the use of the Muslim community in our country, the hadith maudhu 'is also called a false hadith. The purpose of this study is to see what is the origin of the hadith of maudhu 'and its effect on the worship practices of Muslims today. This study is a qualitative study through interviews and document collection in the form of hadith books. The results show that the factor of the emergence of the maudu hadith 'is the presence of the Muslim enemy who wants to destroy the hadith, the fanatical attitude towards the group, the easy attitude towards narrating the hadith, the attitude of the self and seeking public fame, ignorance of the true teachings of Islam. The effect of hadith maudhu 'is damaging to the faith of Muslims, it is damaging to the shariah practice of Muslims, it is damaging to the morals of Muslims, it is damaging to Muslims, it is disregarding authentic hadiths. Therefore, researchers suggest that Muslims should be more careful in understanding a hadith and practicing it, because it is feared that it is a maudu 'or false hadith. 
Keyword: Hadis Maudu', Amalan, Dampak hadis.

\section{PENDAHULUAN}

Hadis ialah sumber hukum Islam yang menjadi menjadi rujukan bagi memahami ajaran Islam setelah $\mathrm{Al}$-quran. Kewujudannya semasa hidup Nabi Muhammad s.a.w. sebagai tafsir dari AlQuran. Kerana hadis memiliki erti penting, ianya pun banyak dibuat palsu sehingga dikenal juga dengan hadis palsu. Istilah Hadis Maudhu' adalah berasal daripada dua perkataan di dalam bahasa Arab iaitu perkataan al-Hadis dan perkataan al-Maudhu'. Al-Hadis dari segi bahasa mempunyai beberapa pengertian seperti al-hadis dengan erti baharu (aljadid) dan al-hadis dengan erti cerita (alkhabar). ${ }^{1}$ Dari sudut definisi syara', hadis memiliki erti setiap apa yang dikaitkan kepada Nabi Muhammad s.a.w, sama ada perkataan, perbuatan, taqrir, sifat akhlaq dan sifat semulajadi. Pengertian ini sama dengan pengertian yang dibuat oleh ulama hadis terhadap al-Khabar dan al-Athar. ${ }^{2}$ Sebahagian ulama hadis pula mendefinisikan al-Hadis sama erti dengan al-Sunnah. Hal ini boleh dilihat dengan apa yang disebutkan oleh Ibnu Hajar alAsqalani yang mengatakan keempat-empat perkataan ini membawa maksud yang sama (walaupun tidak dipersepakati oleh semua ulama). Walau bagaimanapun, ia menambah dalam pengertian beliau, "sesuatu yang disandarkan kepada Nabi atau sahabat atau tabi'in."

\footnotetext{
${ }^{1}$ Ijaj al-Khatib, Ushul Al-Hadist Ulumubu Wa Mushtalabubu (Beirut, 1981), h. 26-27.

${ }^{2}$ Jamaluddin al-Qasimi, Qaqaid Al-Tabdist Min Funun Mushthalab AlHadits Beirut: Dar AlNafa'is, 1993) (Beirut: Dar al-Nafa'is, 1993), h.61.

3 Ahmad bin Hajar al-Asqalani, Syarh Nukbbah Al-Fikear Fi Musthalah Ilm al-Atsar (Bairut: Dar al-Fikr), h.2.
}

Perkataan al-Maudhu' pula, dari sudut bahasa berasal daripada perkataan wadha'a - yadha'u - wadh'an wa maudhu'an - yang mengandungi beberapa pengertian antaranya telah menggugurkan, menghinakan, mengurangkan, melahirkan, merendahkan, mencipta, menanggalkan, menurunkan dan lain-lain lagi. Walaubagaimanapun, erti yang paling sesuai untuk dipadankan dengan perkataan al-Hadis bagi menghasilkan makna yang dikehendaki di dalam perbincangan Hadis ialah makna 'telah mencipta'. Oleh itu Maudhu' (di atas neraca isim maful benda yang kena buat) akan membawa erti dicipta atau direka. Berdasarkan pengertian al-Hadis dan al-Maudhu' ini, dapatlah dibuat kesimpulan bahawa definisi Hadis Maudhu' adalah sesuatu yang disandarkan kepada Nabi Muhammad s.a.w samaada perbuatannya, perkataannya, taqrirnya, sifat akhlaqnya atau sifat semulajadinya, secara rekaan atau dusta semata-mata. Di dalam penggunaan masyarakat Islam di negara kita, hadis maudhu' disebut juga dengan nama hadis palsu.

Di dalam definisi yang lebih tepat lagi ulama hadis mendefinisikannya sebagai apa-apa yang tidak pernah keluar daripada Nabi s.a.w samaada dalam bentuk perkataan atau perbuatan atau taqrir, tetapi disandarkan kepada Baginda s.a.w sama ada secara sengaja atau tersalah, jahil atau memperdaya. Menurut pendakwah Islam, kategori hadis maudhu' juga ialah dakwaan-dakwaan sesetengah golongan tariqat bahawa silsilah tariqat mereka adalah daripada Nabi Muhammad s.a.w padahal perkara tersebut tidak dapat mereka buktikan walaupun berdasarkan hadis-hadis daif. Maka, ini juga boleh 
digolongkan sebagai hadis maudhu'. Ini berdasarkan definisi hadis maudhu' yang lain di mana setengah ulama hadis mendefinisikannya sebagai pembohongan yang dicipta dan disandarkan kepada Nabi Muhammad s.a.w. ${ }^{4}$

\section{Sejarah dan Faktor Kewujudan Hadis Maudhu'}

Selepas zaman sahabat, berlaku kelemahan dalam penelitian hadis-hadis, tidak seperti di zaman sahabat. Ini menyebabkan berlaku banyaknya periwayatan-periwayatan dan penyebaran hadis yang secara tidak langsung telah turut menyebabkan berlakunya pendustaan terhadap Rasulullah. Ditambah lagi dengan konflik politik di antara umat Islam yang semakin hebat, telah membuka peluang kepada golongan tertentu yang cuba mendekatkan diri dengan pemerintah dengan mencipta hadis.

Hal lain daripadanya, kemasukan secara ramai penganut agama-agama lain ke dalam Islam, hasil daripada penyebaran dakwah ke pelusok dunia, secara tidak langsung menjadi faktor kepada bermulanya penciptaan hadis-hadis maudhu'. Tidak dapat dinafikan terdapat sebahagian daripada mereka memeluk Islam kerana benar-benar ikhlas dan tertarik dengan kebenaran ajaran Islam. Namun begitu terdapat juga segolongan daripada mereka yang menganut agama Islam hanya kerana terpaksa mengalah kepada kekuatan Islam pada masa itu. ${ }^{5}$

Golongan ini sentiasa menyimpan dendam dan dengki terhadap Islam dan penganutnya dan sentiasa menunggu

${ }^{4}$ Mahmud al-Tahhan, Taisir Mushtalah AlHadist (Beirut: Dar Al-Quran al-Karim, 1979); Fauzi Deraman, Ulum Al-Hadith (Selangor: Open University Malaysia, 2009).

5 Muhammad bin Muhammad Abu Syahbah, Al-Israiliyyat Wa al-Maudhuat Fi Kutub alTafsir (Maktabah al-Sunnah, 1426), h.20. peluang yang ada bagi merosakkan dan menimbulkan keraguan di dalam hati orang ramai terhadap Islam. Antara peluang yang terbaik ialah semasa pemerintahan Sayyidina Uthman bin Affan (w. $35 \mathrm{H}$ ), hasil daripada sikap tolak ansur dan lemah-lembut akhlaknya terhadap orang ramai, golongan ini mula menaburkan benih-benih fitnah yang pertama.

Antara individu yang memainkan peranan ini ialah Abdullah bin Sabak, seorang Yahudi yang mendakwa telah memeluk Islam. Dengan bertopengkan pembelaan dan kasih kepada Sayyidina Ali dan ahli Bait, beliau menjelajah ke segenap pelusuk untuk menabur fitnah kepada orang ramai. Beliau mendakwa Ali (w. $40 \mathrm{H}$ ) yang lebih layak menjadi khalifah daripada Uthman bahkan daripada Abu Bakar (w. 13H) dan Umar (w. 23H), kerana ianya telah diwasiatkan oleh Nabi s.a.w. Lalu, beliau dipercayai telah mencipta satu hadis maudhu' yang bermaksud: "Setiap Nabi itu ada penerima wasiatnya dan penerima wasiatku adalah Ali." Kemunculan Ibnu Sabak ini dikatakan berlaku di akhir pemerintahan Uthman. ${ }^{6}$

Walaubagaimanapun, penyebaran hadis maudhu' pada masa ini belum lagi meluas disebabkan kewujudan ramai para sahabat-sahabat utama yang mengetahui dengan penuh yakin akan kepalsuan sesuatu hadis. Sayyidina Uthman sebagai contohnya, apabila mengetahui hadis maudhu' yang dicipta oleh Ibnu Sabak, telah mengambil tindakan dengan menghalau Ibnu Sabak dari bumi Madinah. Begitu juga dilakukan oleh Sayyinia Ali selepas daripada itu.

Walaupun begitu, kumpulan ini terus mengambil peluang yang ada, terutama selepas pembunuhan Uthman.

6 Said Ramadhan al-Buti, Fiqh Al-Sirah (Beirut: Dar al-Fikr, 1980), h. 369. 
Munculnya kumpulan-kumpulan tertentu seperti kumpulan yang kononnya ingin menuntut bela di atas kematian Uthman, kumpulan yang menyokong Ali mahupun kumpulan yang tidak memihak kepada mana-mana dua kumpulan ini, menyebabkan hadis-hadis yang menunjukkan kelebihan kumpulan masing-masing dicipta untuk mempengaruhi orang ramai.

Dari senarai di atas, boleh dikata beberapa hal yang menjadi pelbagai faktor kewujudan hadis-hadis maudhu' yang diciptakan oleh pereka-pereka hadis. Salah satu sebabnya ialah musuh terhadap Islam. Perkara ini banyak dilakukan oleh kumpulan sesat di luar sana yang tewas dengan kekuasaan Islam. Mereka memalsukan hadis dengan tujuan mahu menyesatkan umat Islam dari segi hati dan pemikiran mereka. Golongan ini adalah ahli Zindiq, Yahudi, Majusi dan Nasrani golongan ini menampakkan keislamannya dan menyembunyikan kekafirannya. Ini berdasarkan kepada peristiwa Abdullah bin Sabak yang cuba untuk memecah belahkan umat Islam. Oleh sebab zaman tersebut masih ramai lagi sahabat-sahabat ulama yang masih hidup. Mereka ini tidak mampu menghancurkan Islam secara terbuka lalu mereka memilih cara yang keji ini.

Seterusnya ialah mempunyai sikap fanatik terhadap kumpulan. Sikap ini mula timbul hasil dari perpecahan umat Islam kepada kumpulan-kumpulan tertentu dalam politik, aqidah,feqah dan sebagainya. Selepas itu perpecahan umat Islam semakin merebak pula kepada perpecahan dalam perkara-perkara yang berkaitan aqidah. Hasil daripada inilah munculnya hadis-hadis maudhu' yang

7 LIhat selengkapnya Abdul Wahhab Fayyid, Al-Dakbiil Fi Tafsir al-Qur'an. (Kairo: Matba'ah al-Hadirah al-Alarabiyah, 1980); Syahbah, Israilliyat, vol.4 h. 89-92. menyebutkan kelebihan tentang kumpulan masing-masing. Terutama fahaman kumpulan-kumpulan politik setelah berlaku fitnah dan kemunculan kumpulan politik seperti Khawarij dan Syiah. Setiap kumpulan menciptakan hadis masingmasing bagi menyokong fahaman mereka. ${ }^{8}$

Justeru itu, faktor lain adalah sikap ambil mudah dalam meriwayatkan hadis. Menjadi permasalahan di sini apabila hadis yang disampaikan tidak diperhatikan terlebih dahulu statusnya samaada ia benar-benar menurut penilaian para hadis atau sekadar perkataan yang bersandarkan secara dusta keatas nama kemuliaan baginda SAW. Hal ini disebabkan mereka ini sudah lanjut usia serta kurang dalam mendalami pembelajaran hadis. Oleh itu, mereka haruslah sedar diri dan lebih terbuka ketika dikritik yang paling besar supaya hal ini tidak berterusan dan menjadi sebahagian yang rosak dalam kalangan islam.

Di samping itu, hadis maudhu' berpunca dari sikap kepentingan diri dan mencari kemasyhuran orang ramai. Mencari kepentingan dunia, seperti mengambil hati pemimpin, dan mendapatkan kedudukan yang istimewa pada hati pemerintah. Golongangolongan ini sebahagian mereka adalah terdiri daripada pencerita yang cetek ilmu pengetahuan, kekurangan akal dan agama sedangkan ketiga-ketiga perkara ini menjadi asas kepada seseorang yang ingin menyampaikan ajaran yang berkaitan dengan agama Islam. Mereka tidak memikirkan tujuan lain melainkan mahukan orang ramai berhimpun dalam majlis-majlis mereka. Di situlah mereka mula mencipta apa sahaja hadis yang boleh meninggalkan kesan kepada orang ramai. Mereka tidak mengangap apa yang mereka lakukan adalah suatu

\footnotetext{
${ }^{8}$ Fayyid, vol.2 h.13.
} 
pembohongan dan dosa terhadap Nabi S.A.W. ${ }^{9}$

Tambahan lagi, Kejahilan tentang ajaran Islam yang sebenar dengan mencipta hadis-hadis maudhu'. Mereka mengemukakan hadis-hadis pelik yang tidak ada pada syeikh- syeikh hadis lalu mereka memalingkan sanad hadis supaya ia kelihatan berbeza lalu ia dapat menarik minat orang untuk mendengarnya. Tujuan yang dinyatakan untuk mendekatkan diri kepada Allah SWT akan tetapi mereka mencipta hadis-hadis yang menakutkan dari melakukan kemungkaran. Golongan adalah golongan zuhud iaitu kumpulan yang paling jahat kerana orang ramai menerima hadis-hadis mereka kerana melihat kewarakan dan kesalihan golongan ini dan seterusnya membenarkan apa sahaja yang diucapkan oleh mereka. ${ }^{10}$ Walau bagaimanapun masih ramai lagi tabi'in yang menjaga hadis-hadis dan menjelaskan di antara yang lemah dan yang sahih. Sebab itu para ulama tidak berhenti menyebarkan ilmu dan dakwah agar umat islam tidak sesat dalam hidup mereka.

\section{TANDA-TANDA HADIS MAUDHU'}

Dalam menjaga kesinambungan Sunnah, para ulama telah menetapkan berbagai peraturan dan syarat yang berkaitan dengan Sunnah atau Al-Hadis, salah satunya adalah tentang tanda-tanda hadis palsu. Imam Ibnu Hajar al-'Asqalani menyatakan dalam 'Nuzhah al-Nazar' bahawa tanda-tanda hadits palsu dapat diperhatikan melalui keadaan atau kedudukan naratif (sanad) dan juga isi naratif (matan).

\section{Kaedah Pertama: Kajian Sanad}

Tanda-tanda hadis palsu bagi sanad, menurut mushtafa as-Siba'i, antaranya ${ }^{11}$ :

a. Perawi telah berikrar atau membuat pengakuan bahawa dia telah mencipta hadis tersebut. Penyampai hadis dikenali sebagai pembohong dan tidak ada tsiqah (dipercaya) yang menceritakan hadis selain dirinya. Maksudnya, hadis hanya diriwayatkan oleh pembohong.

b. Pengakuan telah terbukti bahawa dia telah berdusta. Contohnya, dia berkata bahawa dia telah mendengar hadis ini daripada syeikh sekian di tempat sekian, sedangkan syeikh tersebut diketahui tidak pernah masuk atau sampai ke tempat tersebut. Untuk pengetahuan kita semua, para ulama telah memberi perhatian yang besar untuk mengetahui pembohong dari para penyampai hadis, mengetahui sejarah hidup mereka dan dengan teliti mengikuti kebohongan mereka dalam hadis tidak seorang pun dari mereka melarikan diri.

c. Perawi terkenal sebagai seorang pemalsu hadis Nabi SAW Pengikrafan yang dilakukan oleh pemalsu hadis. Dia mendakwa bahawa dia telah memalsukan hadis. Seperti tradisi yang menceritakan mengenai kelebihan al-Quran yang diriwayatkan oleh Maisarah bin Abdu Rabbihi al-Farisi dia telah mengakui untuk memalsukan hadis itu.

\section{Kaedah Kedua: Kajian Matan}

Menurut Abdul Madjid al-Ghauriy ciri-ciri dari hadis maudhu' dari kajian

11 Mushthafa As-Siba'i, As-Sunnah Wa Makanatuba Fi At-Tasyri' Al-Islami (Al- Maktabah Al-'Ashriyah, 1985), h.95-101. 
matan ada 12 ciri. $^{12}$ Sama ada ciri-ciri tersebut sebagaimana sebagian juga disebut Mustafa as-Siba’i. Beliau menilai ada tanda-tanda hadis palsu bagi matan ialah $^{13}$ lafaz tidak fasih, makna yang berlaku berosakan, bertentangan dengan makna sahih, tidak berlandaskan fakta sejarah, kesaksian tidak jelas dan terkadung di dalam teks hasid perkara bid'ah. Uraian lengkapnya sebagai berikut:

a. Lafaz tidak fasih

Lafaz yang disampaikan lemah dan janggal, tidak senang didengar oleh telinga dan ditolak oleh tabi'ie .Apabila Lemah (tidak fasih) lafaz adalah mustahil untuk keuar dari mulut orang yang fasih berbahasa Arab. Dia juga tidak boleh meninggalkan orang yang paling fasih. Nabi Muhammad SAW. Daripada AlHafizh Ibn Hajar berkata "Lokasi kepalsuannya jika dia diiringi oleh pengakuan bahawa lafaz itu memang berasal dari Rasulullah SAW “

b. Makna yang berlaku kerosakan Terdapat teks hadis bercanggah dengan teks hadis sahih yang lain. Ia juga bertentangan dengan naluri, penyaksian dan ilmu sains (penemuan ilmiah moden yang sahih dan tidak bertentangan dengan al-Quran, hadis dan sumber-sumber utama di dalam agama). Boleh dijadikan contoh apabila ia melanggar perkaraperkara yang telah dipastikan oleh sebab tanpa kemungkinan untuk ditetapkan atau jika ia melanggar peraturan am dalam undang-undang dan moral, atau jika ia menggalakkan nafsu dan tindakan merosakkan atau melanggar perkara yang dapat dirasakan dan melihat, atau

12 Syed Abdul Majid Ghauri, Pengenalan Ilmu Musthalah Hadits (Malaysia: Darel Syakir, 2011).

13 Mushthafa As-Siba'i, As-Sunnah Wa Makanatuba Fi At-Tasyri' Al-Islami (Al- Maktabah Al-'Ashriyah, 1985), h.96-101. melanggar peraturan-peraturan am dalam melanggar peraturan-peraturan am dalam dunia perubatan atau melanggar prinsipprinsip kesucian Allah Taala ,atau mengandungi hal-hal remeh yang tidak dapat diterima oleh manusia orang yang waras. Contoh hadis palsu: "Perahu Nuh melakukan tawaf di Kaabah tujuh kali dan doa di Ibrahim adalah dua rakaat."

c. Ia bertentangan dengan makna sahih (jelas)

Di dalam al-Quran dan Hadis Mutawatir atau ia juga bertentangan dengan peraturan umum yang diambil dari al-Quran dan Sunnah .Ia juga bercanggah dengan ijma' para sahabat R.anhum. Contoh hadis palsu : "Anak perzinahan tidak akan masuk syurga hingga tujuh keturunan." Ini bertentangan dengan firman Allah Taala dalam Surah AlAn'aam ([6] :164), yang ertinya, "Orang berdosa tidak akan menanggung dosa orang lain." Sebagai contoh, hadis palsu: "Jika kamu mengatakan hadis dari saya yang sesuai dengan kebenaran, maka ambilnya, saya benar-benar telah mengatakannya atau tidak." Kalimat ini bertentangan dengan mutawatir hadis, "Barangsiapa yang berbohong padaku, maka dia duduklah di negara."

d. Ia tidak berlandaskan fakta-fakta sejarah

Ia tidak seperti fakta-fakta yang diketahui pada saat Nabi SAW.Ia terkandung di dalam Hadis perkaraperkara yang didapati melampau yang mustahil bagi seorang Nabi SAW mengucapkan kata-kata tersebut. Contoh hadis palsu yang dikaitkan dengan Anas bin Malik: "Saya memasuki tempat mandi (Hammam) dan saya melihat Nabi duduk dan dia memakai mi'zar. Jadi saya juga ingin bercakap dengannya. Kemudian dia berkata, "Hai Anas, dilarang memasuki kamar mandi tanpa menggunakan mi'zar." 
Hadis ini bertentangan dengan fakta sejarah , kerana Rasulullah SAW tidak pernah memasuki kamar mandi, dan tempat mandi (al-hammam) belum diketahui di Hijjaz pada zaman Nabi .

e. Kesaksian tidak jelas

Jika hadis mengandungi sesuatu yang harus disebutkan oleh ramai orang ,kerana ia terjadi dengan kesaksian banyak orang ,tetapi ternyata ia hanya diriwayatkan oleh satu orang. Contohnya adalah hadis tentang pelantikan Rasul kepada Ali bin Abi Talib sebagai Khalifah penggantinya.

f. Ia terkandung di dalam teks hadis perkara-perkara bid'ah

Diada-adakan dan tidak mempunyai asal serta perawi tersebut termasuk di dalam orang yang menyeru kepadanya. Jika dia terlalu berlebihan dia memberi ganjaran yang sangat besar untuk tindakan kecil atau berlebihan dalam memberi ancaman penyeksaan dalam kes ringan. Sebagai contoh hadis palsu yang berbunyi, "Barangsiapa yang berdoa dan banyak kali, dia akan diberikan ganjaran kepada tujuh puluh nabi."

\section{KESAN HADIS MAUDHU' BAGI UMAT ISLAM}

Menurut salah seorang pengkaji hadis masa kini, Syeikh Abd. Fattah Abu al-Ghuddah menyatakan, hadis-hadis palsu itu telah memberi kemudharatan dalam pelbagai aspek seperti aqidah, ibadah, akhlak, pemikiran, sosial dan ia telah mencemarkan kesucian Islam dan kebersihannya. $^{14}$ Dan usaha untuk membebaskan diri daripada hadis-hadis palsu ini sangat susah dan memerlukan kepada pembacaan yang berterusan dan

${ }^{14}$ Dalam muqaddimah tahqiq, karya Ali al Qari, Al-Mashnu' Fi Ma'rifat al Hadith al Maudbu' (Aleppo: Maktab al-Mathbu'at al Islamiyyah), h.6. peringatan yang tidak putus. Berikut merupakan antara kesan-kesan hadis maudhu' yang akan menjejaskan ibadah umat Islam. ${ }^{15}$

1. Merosakkan aqidah umat Islam.

Hadis Maudhu' yang berkaitan dengan aqidah pastinya akan merosakkan aqidah umat Islam. Dengan membaca atau mendengar hadis-hadis maudhu' dalam bidang ini, pastinya pendengar yang tidak peka terhadap kepalsuannya akan terpedaya lalu mempercayai sedikitsebanyak isi kandungan hadis tersebut. Keadaan ini menyebabkan kepercayaan atau aqidah seseorang akan terseleweng sedikit demi sedikit. Tanpa disedari pendengar akan muncul dengan satu bentuk aqidah dalam dirinya yang menyalahi ajaran sebenar Islam. ${ }^{16}$

2. Merosakkan amalan syariah umat Islam.

Berkenaan amalan syariat pula, hadis maudhu' juga memberi kesan buruk yang tidak kurang hebatnya. Amalanamalan dalam agama Islam yang pada asalnya begitu mudah untuk diamalkan oleh sesiapa sahaja akhirnya bertukar menjadi satu amalan yang ditakuti oleh penganutnya sendiri. Perselisihan dalam mazhab dan kekerasan dalam hukum menyebabkan amalan syariah atau figh umat Islam lari jauh dari ajaran asal Nabi Muhammad s.a.w.

3. Merosakkan akhlak umat Islam.

Di dalam akhlak pula, hadis-hadis maudhu' berkenaan bangsa, bahasa dan negara akan meniggalkan impak yang besar dikalangan pendengar yang

15 Mustafar Mohd Suki, 40 Kisah Palsu Tetapi Masybur (Selangor: PTS Publishing House, 2015), h.25-27.

16 Abdurrahman Abdul Khaliq, Babaya Hadis Dhaif Dan Maudhu' Dalam Aqidah (Kuala Lumpur: Al-Hidayah, 2003), h.31-35. 
mempercayai bahawa hadis-hadis maudhu' berkenaan. Perkara ini dapat menimbulkan rasa tinggi diri yang dicela oleh agama. Ukhwah Islamiyyah dipinggirkan akibat dari gejala hadis maudhu' itu.

4. Merosakkan pendirian umat Islam.

Berhadapan dengan janji pahala yang lumayan di samping amalan yang ringkas boleh menimbulkan perasaan berpada-pada di kalangan umat Islam. Akibatnya pendirian dan pegangan umat Islam akan menjadi lemah. Amalan yang murni mungkin ditinggalkan kerana terdapat amalan lain yang lebih berbaloi dan menguntungkan. Di penghujung jalan wujudlah umat yang tidak tegas dan tidak bersemangat mengamalkan ajaran Islam.

\section{Mengabaikan hadis sahih.}

Perkara lain yang pasti muncul akibat penyebaran hadis maudhu' ialah pengabaian hadis maqbul/sahih. Sekiranya ditekankan hadis maudhu' dalam sesuatu majlis, hadis sahih akan tersisih dan tidak mendapat tempat yang sepatutnya. Akhirnya orang ramai akan senang apabila mendengar hadis maudhu' dan merasa janggal apabila mendengar hadis sahih. Ini merupakan antara musibah yang pastinya terjadi dalam kecelaruan umat Islam sekiranya, hadis maudhu' terus disebarkan tanpa dikenakan tindakan undang-undang yang tegas terhadap pesalah.

Menurut Pakar Hadis, Jabatan AlQuran dan Hadis, Akademi Pengajian Islam, Universiti Malaya (UM), Prof. Madya Dr. Faisal Ahmad Shah salah satu kesan buruk hadis palsu boleh menjuruskan kepada perpecahan umat Islam. ${ }^{17}$ Golongan yang beramal dengan hadis palsu sering beranggapan amalan

\footnotetext{
Online (Malaysia) $<$ https://www.utusan.com.my/rencana/utama/ba hana-hadis-palsu-1.633814\#ixzz519BBAboj>.
}

17 Redaksi, 'Bahana Hadis Palsu', Utusan mereka sahaja benar, lebih memburukkan keadaan mereka menjadi ekstrem sehingga tidak mahu menerima kebenaran lalu melabelkan kumpulan yang menegur pula sebagai sesat. Salah faham dalam agama boleh berlaku sekaligus mencetuskan ketegangan dan keharmonian dalam masyarakat, paling membimbangkan kecelaruan itu terlalu mudah tersebar luas dengan perkembangan teknologi masa kini sedangkan hadis maudhu itu melanggar hukum syarak dalam Islam, ujarnya.

Mengulas lanjut, Faisal berkata, hadis palsu merupakan kata-kata yang disandarkan kepada Rasulullah SAW sedangkan perkara tersebut tidak pernah disebut, dilakukan atau diperakukan baginda. Apa yang pasti, hadis palsu menjejaskan akidah, memesongkan tentang alam ghaib, fitnah akhir zaman yang berlaku dengan mengamalkan hadis yang tidak disyariat selain terlalu yakin dengan suatu ganjaran pahala atau hukuman tidak benar. Walaubagaimanapun, masalah ini akan terus berlarutan memandangkan tiada institusi yang menapis, menyaring serta mengawalnya apatah lagi dengan perkembangan alam maya yang akan pasti menyukarkan pengekangan penyebaran hadis palsu.

\section{KESIMPULAN}

Semangat ekstrem, syirik melalui perbuatan khurafat, percaya kepada perkara tahyul serta melakukan ibadat tidak mengikut syariat merupakan kesan penyebaran hadis palsu secara meluas dalam kalangan umat Islam. Malaysia antara negara Islam yang terkesan menerusi penyebaran hadis-hadis palsu dalam kehidupan seharian, lebih buruk perkara tersebut tersebar luas seiring perkembangan teknologi terkini. Namun isu lebih besar apabila hadis bersifat maudhu atau palsu itu dijadikan amalan dan kepercayaan sehingga menyesatkan 
akidah umat Islam yang menerimanya tanpa merujuk sumber dipercayai dan bertauliah.

\section{RUJUKAN}

Asqalani, Ahmad bin Hajar al-, Syarh

Nukbbah Al-Fikear Fi Musthalah Im al-Atsar (Bairut: Dar al-Fikr)

As-Siba'i, Mushthafa, As-Sunnab Wa Makanatuba Fi At-Tasyri' Al-Islami (Al- Maktabah Al-'Ashriyah, 1985)

Buti, Said Ramadhan al-, Fiqh Al-Sirah

(Beirut: Dar al-Fikr, 1980)

Deraman, Fauzi, Ulum Al-Hadith (Selangor: Open University Malaysia, 2009)

Fayyid, Abdul Wahhab, Al-Dakbiil Fi Tafsir al-Qur'an. (Kairo: Matba'ah al-Hadirah al-Alarabiyah, 1980)

Ghauri, Syed Abdul Majid, Pengenalan Ilmu Musthalah Hadits (Malaysia: Darel Syakir, 2011)

Khaliq, Abdurrahman Abdul, Babaya Hadis Dhaif Dan Maudhu' Dalam Aqidah (Kuala Lumpur: Al-Hidayah, 2003)

Khatib, Ijaj al-, Ushul Al-Hadist Ulumubu Wa Mushtalabubu (Beirut, 1981)

Qari, Ali al, Al-Mashnu' Fi Ma'rifat al Hadith al Maudbu' (Aleppo: Maktab al-Mathbu'at al Islamiyyah)

Qasimi, Jamaluddin al-, Qaqaid Al-Tahdist Min Funun Mushthalah AlHadits Beirut: Dar Al-Nafa'is, 1993) (Beirut: Dar al-Nafa'is, 1993)

Redaksi, 'Bahana Hadis Palsu', Utusan Online (Malaysia) $<$ https://www.utusan.com.my/re ncana/utama/bahana-hadis-palsu1.633814\#ixzz519BBAboj>

Suki, Mustafar Mohd, 40 Kisab Palsu Tetapi Masyhur (Selangor: PTS Publishing House, 2015)

Syahbah, Muhammad bin Muhammad Abu, Al-Israiliyyat Wa al-Maudhuat Fi Kutub al-Tafsir (Maktabah alSunnah, 1426)
Tahhan, Mahmud al-, Taisir Mushtalah AlHadist (Beirut: Dar Al-Quran alKarim, 1979) 